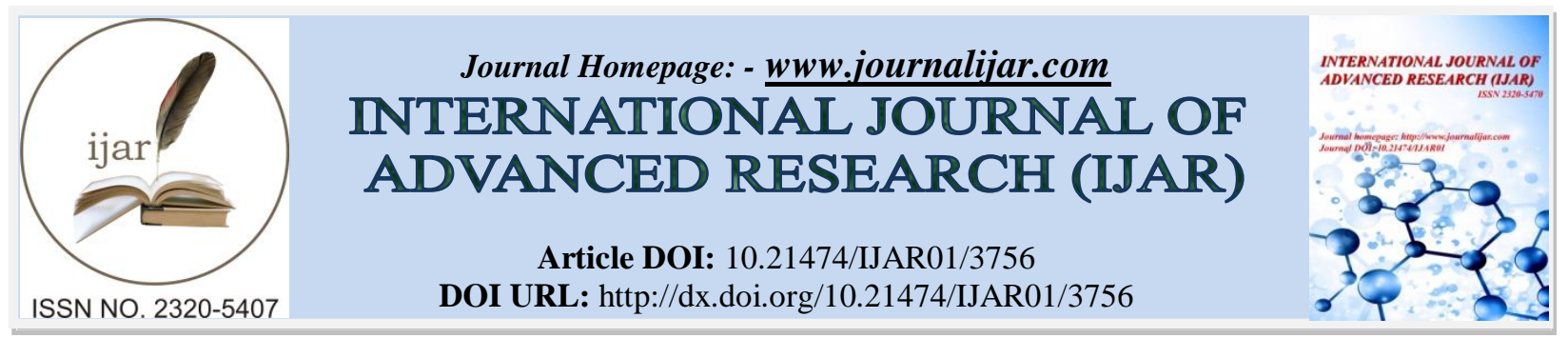

RESEARCH ARTICLE

\title{
RELEVANCE OF BIBLICAL VALUES TO THE MODERN EDUCATIONAL SYSTEM.
}

Dr. J. E. Merlin sasikala ${ }^{1}$ and Dr.T.Ravichandran ${ }^{2}$.

1. Asst. Prof in Education, Alagappa University College of Education, Alagappaa University, Karaikudi.

2. Asst. Prof. of Biological Science, Govt. College of Education, Pudukkottai.

\section{Manuscript Info}

Manuscript History

Received: 16 January 2017

Final Accepted: 11 February 2017

Published: March 2017

Key words:-

Compassion, integrity, forgiveness, loyalty

\section{Abstract}

The present study has great scope in the modern Educational system. We are living in a world which never considers values. Values can change the behavior and attitudes of every one. Value education is important for our students. And Bible always remains us about values. We can see the different teaching methods and techniques used by Jesus Christ and we can also understand that many of them have great relevance today. There are also guiding principles to teachers, parents and students. Bible strongly advocates the need for discipline and it is also helpful for our educational system.

Copy Right, IJAR, 2017,. All rights reserved.

\section{Introduction:-}

"The Bible is no Mere a book, but a living creature, with a power that conquers all that opposite it" "NAPOLEON BONAPARTE(1769-1821)

Bible is like a software, it enters in your life, scan your problems, edit your tension, download solutions, delete your worries and saves you.

A child gets his first education from his family (proverbs 17:6 )" Children are the crown of old men and the glory of children in their father". Little children are Humble, dependent, harmless, godly and deserve to be cherished by parents. Each family believes in certain religion. So there is an interconnection between education and religion believes imparted from the family. Each religion has its own norms and principle and these are conveying through religious books. The thoughts and ideas of bible great related to values.

\section{Bible and values:-}

Philippians 23:4, “don't be Selfish; don't live to make a good impression on others. Be humble, thinking of others as better than yourself. Don't think only about your own affairs, but be interested in others too, and what they are doing .The implies the morality and good character that showed be promoted by a family and educational system on their children. Bible does not teach what method to use, but it does teach what character to build. One of the main aims of Bible is to inculcate virtues among individuals. If the teacher in any setting loves children and promotes Christ like conduct by example, the school conforms to the bible. This does not mean that the child will only learn to love the lord, but that he will also learn to diligent at work, competent in labour, kind in relationships, forgiving in conflict and gracious in judgement. 


\section{Compassion:-}

The definition of "Compassion" simply says that "it is the sympathetic consciousness of others distress along with a desire to alleviateit"

The parable of the good Samaritan (Luke10: 25-37) is a best example for compassion. There are more than to specific references to compassion in the bible. most old testament version refer to the lord`s compassion toward his people and most new testament version refer to Jesus compassion in need.

"Lord will always have compassion on us" ( 2 kings 13:23, Psalm 103:13, Issaiah 54:8)

"Jesus felt compassion on those in need" (matt 9:36, 14:14, Mark 6:34,8:2,15:20)

"Compassion fulfill the law of Christ" ( Galations 6:3)

\section{Loyalty:-}

The world loyalty means unswerving in allegiance as faithful to one`s so vereign or goverm,ent, faithful to a private person to whom fidelity in due faithful to a cause, idial or custom. Bible has to say about loyalty and being loyal.

"Loyalty is unwavering in good times and bad" (proverb17:7)

"Loyalty is what you do, not what you say (Matt26;33-35)

Loyalty is in your heart. It is willing and not Reluctant (psalm78:8)

\section{Forgiveness:-}

Bible says you should forgive seventy seven times. The benefits of forgiveness are

\section{It is necessary for our own forgiveness:-}

1. Jesus said. "But you are Praying, first forgives any one are holding a grudge against, so that your father in heaven will forgive your sins too" (mark11:25, 26)

2. Spiritual cleaning

3. James says that the elders of the church should pray over those who are and lord will make them well, adding "and Anyone who has committed sins will be forgiven" (James 5:15-16)

\section{Integrity:-}

Integrity means firm adherence to a code of moral values, ie, incorruptible, honor;

Bible says about integrity are "Integrity means treating people fairly and honest"(Deut 25:15, Proverbs16:11-

13)“'Integrity is giving your word and keeping it.(Exodus8:28-32)

"Lord Lates lies and lack of integrity (Zachariah 8:16-17)

\section{Moral values:-}

Moral values refer to those values that are related to an individual's character and personality conforming to what is right and virtuous. They reveal a person`s self control. Some of the moral values envisaged in bible are as follows.

\section{Leadership value and Bible:-}

Maintaining one`s values can cost a leader dearly. So how do we decide what matters most who we are weighing the bottom line costs against our bottom line conviction. The first step in effective leadership is defining core values. Until that is done, the ship the leader is trying to steer has no rudder. Vision, mission, strategy and outcomes are difficult-if not impossible to define until values are clear. Jesus knew that. Early in the process of developing his team of disciples, he forced them to confront this foundational issue.

Jesus told his disciples that the core value, the driving value, the internal value is this "Does what I am doing please God" Every other value is second to that one. when that value is in place all other values line up. Mathew 6 is among the most definitive chapters in the bible for shaping a leaders philosophy of life and leadership. Jesus urged his disciples to focus their values on things that would bear an internal return. But how, while making a living on earth, while responsibility leading an enterprise on earth, while providing jobs, product, service and profit on earth, do we build treasure in heaven.

Mathew records Jesus primer on values in mathew6:1. Jesus focused his lesson in version 19-21.Do not- store up for yourselves treasures on earth, where moth and rust destroy, and where thieves break in and steal. But store up for 
yourselves treasures in heaven, where moth and rust do not destroy, and where thieves do not break in and steal. For where your treasure is there your heart will be also.

\section{Bibles quotes about family values:-}

Psalms 127:35 " Children are a heritage from the lord the fruit of womb is a reward, like arrows in the land of a warrior, so are the children of one`s youth. Happy is the man who has quiver full of them".Proverbs 17:6 "Children are the crown of old man and the glory of children is their father"

\section{Ephesians 6:14:-}

'Children obey your parents in the lord, for there is the right, honor your father and mother, which is the first commandment with promise. That it may be well with you and you may live long on the earth. And you father`s, do not provoke your children to wrath, but bring them up in the training and dominations of the lord", Titus 2:4 "they admonish the young women to love their husbands, to their children.

\section{Bible And Discipline:-}

Discipline is essential and important for the development of children. As a matter of fact, it is discipline which makes an individual a dynamic, co-operative, sympathetic and tolerant citizen include with social ideas of service and sacrifice at the cost of his own self-interest. Only this sense of discipline creates such conditions in a school which promotes desirable development of a child. In ancient times, too much importance was given to discipline that it was regarded as an end in itself instead of a means only.

For a well adjured life, development of human and moral qualities are essential, because this qualities make a child cultured and civilized for the purpose of leading one's life happily and also contributing to the welfare of society. To achieve this great aim, disciple is very essential. According to Nunn, "discipline is involved in the control of emotions and powers and it in through that we get the ability to work. The aim of disciple is the creation of virtues and development of personality".

Bible also gave importance to discipline. God uses discipline as a last resort. If all god needed to justify mankind to himself was a bigger cattle-prod, then Christ died for nothing. No, god's plan for the earth is love first, discipline last. To get us to listen and repent, he will use deep conviction, the rebuke of friends, coincident sermons, the quickening of scripture, and every other means before discipline us. But if we resist God's spirit of light and mercy. We are promised the rod of correction. When god disciplines, the punishment fits the crime.

\section{Quotes from Bible about discipline:-}

Prov. 3: 11-12 :- "May son, do not despise the Lord's discipline and do not resent his rebuke, because the Lord disciplines those he loves as a father the son he delights in".

Prov: 15: 5:-" A fool spurns his father's discipline but who ever heads correction shows prudence".

Job 5: 17-18:-"Blessed is the man whom God corrects so do not despise the discipline of almighty for he wounds, but he also binds up, he injured but his hands also heal"

1 Cor 11:32:-"But when God does judge us, the disciplines us as his own sons, that we may not be involved in the general condemnation of the world".

Prov: 20 : 30:-"Blows and wounds cleanse away evil and beatings purge the innermost being".

Rev: 3 : 19:-"Those whom I love I rebuke and discipline. So be earnest and repent".

Child discipline :-"He that loveth his son, frequently chestiseth him, that he may rejoice in his letter end, and not grope after the doors of his neighbours" (Ecc 30:1)

"A horse not broken becometh stubborn and a child left to himself will become head strong" (Ecc. 30:8)

"Give him not liberty in his fourth, and wink not at his devices bow down his neck while he is young, and beat his sides while he is a child, lest he grow stubborn, and regard thee not and so be a sorrow of heart to thee" (Ecc. 30: 11-12)

"He who spareth the rod hateth his son; but he that loveth him correcteth him betimes" (Proverbs 13:24) 
"With hold not correction from a child: for is thou striketh him with a rod he shall not die. Thou shall beat him with a rod, and deliver his soul hell".(Prov. 23: 13-14)

1 Pet 4: 17-19:- "The time has evidently arrived for God's judgment to begin, and it is beginning at his own household. And if it starts with us, what is it going to mean for those who refuse to obey the gospel of God? If even the good man is only just saved, what will be the fate of the wicked and the sinner?... Therefore those who suffer according to god's will can safely commit their souls to their wonderful creator, and go on bound up in the heart of a child, but the rod of discipline will drive it far from him".

Prov. 22: 15:- "Foolishness is bound up in the heart of a child, but the rod of discipline will drive it far from him".

Proverbs 13:24 -- "He who spares the rod hates his son, but he who loves him disciplines him promptly."

Proverbs 19:18 - "Discipline your children while they are young enough to learn. If you don't you are helping them destroy themselves".

Proverbs 21:15 - "Children will naturally do silly, careless things, but a good spanking will teach them how to behave"

Proverbs 23:13 - "Don't hesitate to discipline children. A good spanking won't kill them. As a matter of fact it may save their lives"

Proverbs 23:22 - "Listen to your father. Without him you would not exist. When your mother is old, show her your appreciation"

Proverbs 29:15 - "Correction and discipline are good for children" "Foolishness is bound in the heart of a child; but the rod of correction shall drive it far from him" (Proverbs 22:15)

Withhold not correction from the child: for if thou beatest him with the rod, he shall not die. Thou shalt beat him with the rod, and shalt deliver his soul from hell (Proverbs 23:13-14).

"Correct thy son and he shall give thee rest; yea, he shall give delight unto thy soul "(Proverbs 29:17).

\section{Physical discipline in Bible:-}

The bible is replete with exhortations about discipline and examples of stiff disciplines allowed or brought by the Lord, in both Old and New Testaments. Some examples;

"Folly is bound up in the heart of a boy, but the rod of discipline drives it far away" (Prov. 22:12)

"Do not withhold discipline from your children, if you beat them with a rod, they will not die. If beat them with a rod, you will save their lives from sheol" (Prov. 23: 14-15)

"The rod and reproof give wisdom" (Prov. 29:15) Discipline your children and they will give you rest, they will give delight to your heart" (Prov. $29: 17$ )

"On the lips of one who has understanding wisdom is found, but the rod is for the back of one who lacks sense" (Prov. 10: 27

"Those who spare the rod hate their children, but those who love them are diligent to discipline them" (Prov. 13: 24).

"The Lord disciplines those whom he loves, and scourges every child whom he accepts" (Hebrews 12:6)

Discipline believes that good behaviour is a teachable skill, not unlike math or reading. Because of this, it makes use of the tools that a good teacher would use. Tools like: good relationship/ rapport building, teaching stories following through with logical consequences, real life examples, personal sharing, redirecting, practice, and giving information in respectful, repeated and varied ways. People who use disciple correctly, do not necessary differ in the number of limits they establish.

\section{Conclusion:-}

Values can change the behavior and attitude of every one. Value education is important for our children. And Bible always remains us about values. We can see the different teaching methods and techniques used by Jesus Christ and we can also understand that many of them have great relevance today. There are also some guiding principles to teachers, parents \& students. Bible strongly advocates the need for discipline and it is also helpful for our educational system. 


\section{References:-}

1. Ahuja, Ram(2001) Research methodology. New Delhi: Rawat Publication.

2. Arulandam, H.G.S(1991). "Needed value based Education" New Delhi: Association of Indian Universities

3. Best, John W.(1989) "Research in Education. " New Delhi: Prentice Hall of India. Nazerth,Pia,Walper,

4. E. Maria(1978) "Personal values" " New Delhi: Association of Catholic schools.

5. Gay,L.R(1996) "Educational Research. New Jersey: Prentice Hall of India.

6. Adams, Jay (1970), Competent to Counsel (Phillipsburg, NJ: Presbyterian 85 Reformed).

7. Cosgrove, Mark (1979), Psychology Gone Awry (Grand Rapids: Zondervan). Freud, Sigmund (1949), The Future Of An Illusion (New York: Liveright Publishing).

8. Huxley, Julian (1941), The Uniqueness of Man (London: Chatto 86 Windus).

9. Jackson, Wayne (1998), The Bible \& Mental Health (Stockton, CA: Courier Publications). 